\title{
Article 18. Compliance with Mutually Agreed Terms
}

1. In the implementation of Article 6, paragraph 3(g)(i) and Article 7, each Party shall encourage providers and users of genetic resources and/or traditional knowledge associated with genetic resources to include provisions in mutually agreed terms to cover, where appropriate, dispute resolution including:
(a) The jurisdiction to which they will subject any dispute resolution processes;
(b) The applicable law; and/or
(c) Options for alternative dispute resolution, such as mediation or arbitration.

2. Each Party shall ensure that an opportunity to seek recourse is available under their legal systems, consistent with applicable jurisdictional requirements, in cases of disputes arising from mutually agreed terms.

3. Each Party shall take effective measures, as appropriate, regarding:
(a) Access to justice; and
(b) The utilization of mechanisms regarding recognition and enforcement of foreign judgments and arbitral awards.

4. The effectiveness of this article shall be reviewed by the Conference of the Parties serving as the meeting of the Parties to this Protocol in accordance with Article 31 of this Protocol.

\section{$1 \quad$ Overview}

Specific conditions for the utilization of genetic resources ${ }^{1}$ or the utilization of traditional knowledge must be set out in MAT, which are normally contracts governed by private law. ${ }^{2}$ As already discussed, ${ }^{3}$ MAT are normally established upon access (and can possibly be (re)negotiated at a later stage $)^{4}$ and must

1 See this commentary on Article 2, section 2.

2 See Introduction to this commentary, section 1.3; and Greiber et al., Explanatory Guide, op. cit., 184.

3 Nagoya Protocol Articles 5(1-2) and (5) and 6(3)(g). See this commentary on Article 5, section 5, and Article 6, section 7.

4 See Introduction to this commentary, Section 1.3 and fn. 81. 
primarily include conditions for benefit-sharing, as well as address dispute settlement, third-party use and change of intent. Against this background, Article 18 aims to create the legislative preconditions at the domestic level in order to address procedural challenges for individual providers and users that are located in different countries ${ }^{5}$ arising from situations of non-compliance with MAT - that is, violations of contractual obligations. ${ }^{6}$ This may be critical, for instance, for situations in which the user's intent changes, ${ }^{7}$ particularly if the MAT allowed only non-commercial research. ${ }^{8}$ In these instances, the MAT may create a contractual obligation for users to re-negotiate MAT as soon as commercial research starts, ${ }^{9}$ in the absence of which the provider is entitled to obtain contractual penalties or damages. ${ }^{10}$

Article 18 addresses two issues related to compliance with MAT through three obligations. First, it complements Parties' obligation to detail the minimum content of MAT in domestic ABS frameworks, ${ }^{11}$ by establishing a qualified obligation for Parties to 'encourage' (i.e., at least to remove barriers to, and/ or create incentives for $)^{12}$ the inclusion in MAT of provisions on dispute resolution. Second, it aims to support users' compliance with MAT by establishing an obligation for Parties to 'ensure' an opportunity to seek recourse for disputes on MAT; and a qualified obligation to take domestic measures on access to justice and on the recognition of foreign judgments and arbitral awards. The Protocol, however, does not provide any guidance on how national courts

$5 \quad$ Glowka and Normand, "Nagoya Protocol on Access and Benefit-sharing," op. cit., 36. Свр Working Group on Авs, "Comparative study of the real and transactional costs involved in the process of access to justice across jurisdictions" (26 February 2009) UN Doc UNEP/CBD/WG-ABS/7/INF/4; "Analytical study on administrative and judicial remedies available in countries with users under their jurisdiction and in international agreements" (20 July 2007) UN Doc UNEP/CBD/WG-ABs/5/INF/3; and "Analysis of claims of unauthorised access and misappropriation of genetic resources and associated traditional knowledge" (22 December 2005) un Doc UneP/СвD/WG-ABs/4/INF/6.

The breach of MAT has been termed 'misuse,' in contrast to 'misappropriation' which generally refers to the appropriation of genetic resources and traditional knowledge in violation of the applicable domestic requirements, i.e., generally without PIC and MAT. See Chiarolla, "Role of Private International Law," op. cit., 427-428; and fn. 14 in this commentary on Article 15.

$7 \quad$ Nagoya Protocol Article 6(g)(iv). See this commentary on Article 6, section 7.

$8 \quad$ Nagoya Protocol Article 8(a). See this commentary on Article 8, section 2.

9 That is, 'research and development' for the purposes of the Protocol definition of 'utilization': see Article 2(c) and this commentary on Article 2, section 2.

10 Godt, "Enforcement of Benefit-Sharing Duties," op. cit., 423-424.

11 Nagoya Protocol Article 6(3)(g).

12 On the obligation to encourage, see this commentary on Article 9, section 1. 
should interpret ABS contracts, ${ }^{13}$ regarding for instance the interpretation of the contractual terms on benefit-sharing and the assessment as to whether they are fair and equitable pursuant to the Protocol's objective. Article 18 also calls for a review of its effectiveness by the Protocol's governing body, as part of its general assessment and review process. ${ }^{14}$

The following sections will discuss the three obligations enshrined in Article 18 in turn. The final section will explore the relevance of Article 18 for cases of misappropriation - that is, violation of domestic ABS frameworks (addressed in Articles 15-16).

\section{Dispute Resolution Provisions in MAT}

Article 18(1) aims to 'promote best practice in drafting more easily enforceable ABS contracts. ${ }^{15}$ It obliges each Party to encourage providers and users of genetic resources and/or traditional knowledge to specifically address in MAT how to resolve disputes among them. The implementation of this provision is explicitly linked (and is, in effect, complementary to) Parties' obligation to establish 'clear [domestic] rules and procedures' for requiring and establishing MAT, including a clause on dispute settlement, ${ }^{16}$ and to take appropriate domestic measures to ensure that MAT have been established for access to traditional knowledge associated with genetic resources. ${ }^{17}$

Even where foreigners could enjoy equal access to domestic courts in a certain jurisdiction, there is broad understanding that further measures are needed for foreign users or providers wishing to bring legal action before a court of a State other than that in which they are based. ${ }^{18}$ This may be particularly the case of providers that lack the resources and knowledge of the relevant legal system to bring a case, probably of a long duration, in another country, in order to obtain redress from a user that has allegedly violated the ABS contract. In order to cope with these obstacles, the Bonn Guidelines already elaborated on suggested elements for MAT, such as change of use, dispute settlement and choice of law, as well as permitted uses, IPRs, commitment to share monetary

\footnotetext{
13 Tvedt, “Beyond Nagoya," op. cit., 163.

14 Nagoya Protocol Article 18(4). See this commentary on Article 31.

15 Glowka and Normand, "Nagoya Protocol on Access and Benefit-sharing," op. cit., 36.

16 Nagoya Protocol Article 6(3)(g)(i).

17 Nagoya Protocol Article 7.

18 Hiroji Isozaki, "Enforcement of ABs Agreements in User States," in Kamau and Winter, Genetic Resources, Traditional Knowledge, and the Law, op. cit., 442.
} 
and non-monetary benefits, and termination of the agreement. ${ }^{19}$ The aim was for detailed guidance to increase the chances for a court to come to an unambiguous decision thanks to the fact that the contract under dispute is sufficiently clear and specific. ${ }^{20}$ In that regard, the Bonn Guidelines appear more detailed than the Nagoya Protocol. In addition, it should be borne in mind that the Hague Conference on Private International Law, the Un Commission on International Trade Law and the International Institute for the Unification of Private Law ${ }^{21}$ have been working on judicial cooperation among countries in facilitating the judicial process for foreign applicants, ${ }^{22}$ including towards the harmonization of legal systems on civil and commercial law.

Article 18(1) sets out three legal issues related to transboundary contractual dispute resolution. First, it underlines the importance for parties to MAT to identify the jurisdiction to which they will subject any dispute resolution process (that is, MAT should explicitly clarify in which jurisdiction a MAT-related dispute will be brought). ${ }^{23}$ It has been noted that providers may prefer to bring an action for breach of MAT in the jurisdiction of the user, with a view to obtaining a judgment that can be directly enforced against the user in his/ her own jurisdiction. ${ }^{24}$ Absent such identification, legal uncertainty will arise as to whether a national court in a given country where legal action has been

19 Bonn Guidelines, Appendix I.

$20 \quad$ Isozaki, “Enforcement of ABs Agreements in User States," op. cit., 442.

21 Ibid. See Convention on Abolishing the Requirement of Legalization for Foreign Public Documents (The Hague, 5 October 1961, in force 24 January 1965) 20 ILM 1405; Convention on the Service Abroad of Judicial and Extrajudicial Documents in Civil or Commercial Matters (The Hague, 15 November 1965, in force 10 February 1969); Convention on the Taking of Evidence Abroad in Civil or Commercial Matters (The Hague, 18 March 1970, in force 7 October 1972) 8 ILM 37; Convention on International Access to Justice (The Hague, 25 October 1980, in force 1 May 1988) 19 ILM 1505; Convention on Civil Procedure (The Hague, 1 March 1954, in force 12 April 1957); Convention on the Jurisdiction of the Selected Forum in the Case of International Sales of Goods (The Hague, 15 April 1958, not yet in force); Convention on the Choice of Court (The Hague, 25 November 1965, not yet in force); Convention on the Recognition and Enforcement of Foreign Judgments in Civil and Commercial Matters (The Hague, 1 February 1971, in force 20 August 1977) 5 ILM 636; Supplementary Protocol of to the Hague Convention on the Recognition and Enforcement of Foreign Judgments in Civil and Commercial Matters (The Hague, 1 February 1971, in force 20 August 1979) 6 ILM 1083; Convention on the Choice of Court Agreements (The Hague, 30 June 2005, not yet in force).

22 Isozaki, "Enforcement of ABs Agreements," op. cit., 442.

23 Chiarolla, "Role of Private International Law," op. cit., 430.

24 Singh Nijar, The Nagoya Protocol on Access and Benefit Sharing of Genetic Resources, op. cit., 12 . 
brought will deem to have competence to consider a dispute concerning MAT. Provided that the jurisdiction to which dispute resolution processes will be subjected is clarified in MAT, the decision on which court will have competence will be made on the basis of domestic norms applicable in the given country, unless an international or regional instrument for judicial cooperation is applicable. ${ }^{25}$

Second, Article 18(1) underscores the importance for parties to MAT to identify in their contract the substantive law to be applied to resolve any dispute among them. Absent such a clause, legal uncertainty will arise as the determination of the law that will govern the dispute, which would be left to the domestic court where legal action has been brought, on the basis of the domestic norms on private international law in its jurisdiction. The question of applicable law is particularly complex in the context of private-law contracts. The domestic court may have to make a choice, on the basis of private international law norms and taking into consideration the interest of the parties, between two different sets of law, such as for instance its own domestic law or the law of another country, or it may decide that different questions in a given case may be governed by different countries' law. ${ }^{26}$

Third, Article 18(1) highlights the important possibility for parties to MAT to agree up-front to settle disputes through alternative dispute resolution mechanisms rather than domestic courts. ${ }^{27}$ This may be useful when such nonjudicial means entail higher flexibility, simpler procedures and lower costs than judicial mechanism. ${ }^{28}$ The provision explicitly mentions mediation or arbitration, but does not exclude that parties to MAT may also agree to have recourse to other mechanisms, including community-based dispute resolution systems or an international institution that may facilitate the resolution of the dispute. With regard to the latter, it is noteworthy that during the negotiations of the Protocol the creation of an international ombudsman had been proposed in relation to this provision. ${ }^{29}$ As discussed below in more detail, ${ }^{30}$ this proposal has been revived in the context of negotiations on the Protocol's

\footnotetext{
25 Greiber et al., Explanatory Guide, op. cit., 185.

26 Godt, "Enforcement of Benefit-Sharing Duties," op. cit., 423.

27 See for instance Article 8 of the ITPGRFA SMTA which provides for the following steps on dispute resolution: amicable dispute settlement, mediation and arbitration.

28 Isozaki, "Enforcement of ABs Agreements in User States," op. cit., 446.

29 We are grateful to Geoff Burton for drawing our attention to this point. See also Greiber et al., Explanatory Guide, op. cit., 190-191; Chiarolla, "Role of Private International Law," op. cit., 433 and note 29; and свр Working Group on ABs, "Collation of operative text submitted," UNEP/CBD/WG-ABS/7/5, 27-28.
}

See this commentary on Article 30, section 3.2. 
compliance procedures and mechanisms that are ongoing at the time of writing. With regard to the former, Parties' obligation to encourage parties establishing MAT to include alternative dispute resolution mechanisms as options should be interpreted and implemented taking in due consideration indigenous and local communities' customary laws and procedures, when these communities are concerned by the ABs transaction. ${ }^{31}$

Finally, it has been noted that the Protocol glosses over the complexity of utilizing alternative dispute resolution mechanisms generally used in commercial law disputes for the purposes of achieving fair and equitable benefitsharing, and that in that connection development of guidance by the Protocol's governing body would be useful. ${ }^{32}$

Article 18(2) aims to ensure opportunities to seek recourse in any Party's legal systems in case of cross-border dispute arising from MAT. ${ }^{33}$ This may be particularly complicated as domestic rules may vary on (and possibly prevent) standing for foreign government entities or for non-incorporated collective entities such as an indigenous or local community that is party to MAT. ${ }^{34}$

Language from the ITPGRFA ${ }^{35}$ was relied upon in the drafting of Article 18(2), thereby obliging Parties to provide in their domestic legal systems for existing or new mechanism for parties to MAT to settle their contractual disputes. Article 18(2) arguably aims to ensure that some remedies against breaches of MAT will be made available in all jurisdictions independently of the nationality of the claimant, ${ }^{36}$ taking into account de facto barriers such as costs and differing requirements about the entitlement to bring legal actions before foreign courts.

$31 \quad$ Nagoya Protocol Article 12(1): see this commentary on Article 12, section 2.

32 Young, "An International Cooperation Perspective," op. cit., 488. See this commentary on Article 26, section 2.

33 Glowka and Normand, "Nagoya Protocol on Access and Benefit-sharing," op. cit., 36.

34 Godt, "Enforcement of Benefit-Sharing Duties," op. cit., 422.

35 ITPGRFA Article 12(5), which reads: 'Contracting Parties shall ensure that an opportunity to seek recourse is available, consistent with applicable jurisdictional requirements, under their legal systems, in case of contractual disputes arising under such MTAs, recognizing that obligations arising under such MTAs rest exclusively with the parties to those MTAs' (emphasis added). On the interpretation of this provision, see Moore and Tymowski, Explanatory Guide to the International Treaty, op. cit., 100-101.

36 Greiber et al., Explanatory Guide, op. cit., 186. 
The Protocol, however, does not provide guidance on how the courts should decide whether they have jurisdiction over MAT-related disputes. ${ }^{37}$ The expression 'consistent with applicable jurisdictional requirements' of the Party concerned has been interpreted as an acknowledgement or a safeguard clause that the availability of recourse to courts will depend on applicable rules on the choice of jurisdiction, as established in contracts and accepted by the named court, or in their absence by [the] private international law of the seized forum. ${ }^{38}$ Fundamentally, Article 18(2) places a duty on Parties to provide to individual parties to MAT opportunities to seek recourse in other Parties and arguably to ensure that when such recourse is provided, the seized forum 'should assert jurisdiction unless the complaint is apparently based on dubious grounds (e.g., where none of the parties to the MAT have real connection with the forum). 39

Access to Justice and Recognition of Foreign Judgments

Article 18(3) requires the development of domestic measures on access to justice and utilization of mechanisms of mutual recognition and enforcement of foreign judgments and arbitral awards, ${ }^{40}$ with a view to supporting providers that usually do not have easy access to courts in third countries. ${ }^{41}$

It has been noted that in the context of Article 18 the reference to 'each Party' indicates that the requirement targets the unilateral development of domestic measures, rather than the multilateral development of harmonized requirements. ${ }^{42}$ It may also serve to underline that both Parties that see themselves as mostly user countries or provider countries have to develop such domestic measures.

Article 18(3)(a) obliges Parties to take effective measures, as appropriate, regarding access to justice. While the term 'access to justice' is not defined in the Protocol, it has particular resonance in international environmental law. In the latter context, it is generally seen as a necessary tool for the enforcement of environmental law and as a means for reviewing the decisions, acts, and

37 Chiarolla, "Role of Private International Law," op. cit., 431.

38 Ibid., 432. See also Greiber et al., Explanatory Guide, op. cit., 186.

39 Chiarolla, "Role of Private International Law," op. cit., 432.

40 Glowka and Normand, "Nagoya Protocol on Access and Benefit-sharing," op. cit., 36.

41 We are grateful to Geoff Burton for drawing our attention to this point.

42 Greiber et al., Explanatory Guide, op. cit., 187. 
omissions of public authorities with regard to environmental matters. ${ }^{43}$ Access to justice is well-established in international human rights law ${ }^{44}$ in relation to the independence and impartiality of a court with a view to ensuring a fair trial, and 'truly effective' remedies in determining that a violation has occurred and in providing redress. ${ }^{45}$ It has thus been argued that human rights standards may be used as a yardstick to ensure that access to justice has been provided in a specific case under the Protocol. ${ }^{46}$

Under Article 18(3)(b), Parties have an obligation to adopt effective measures addressing the utilization of mechanisms for the recognition and enforcement of foreign judgments and arbitral decisions. In other words, they are to support participation in existing mechanisms or establish new ones if they do not exist. ${ }^{47}$ Recognition of foreign judgments remains a complex matter, ${ }^{48}$ whereas the recognition of foreign arbitral awards may be considered 'generally easier' as a high number of countries are Parties to the 1958 New York Convention on

43 See Rio Declaration Principle 10; and Guidelines for the development of national legislation on access to information, public participation and access to justice in environmental matters, adopted by UNEP Governing Council in decision SS.XI/5, part A, 26 February 2010, accessed 30 November 2013, <www.unep.org/civil-society/ Portals/24105/documents/Guidelines/GUIDELINES_TO_ACCESS_TO_ENV_INFO_2. pdf $>$. See also Ebbesson, "Access to Information on Environmental Matters," op. cit., particularly paragraphs $31-33$, who concludes that 'Despite the close link to the notions of access to information and public participation in decision-making on environmental matters, access to justice remains a less established concept than the latter two in international environmental law,' emphasis added, paragraph 33.

44 E.g. Article 14 ICCPR; Francesco Francioni, ed. Access to Justice as a Human Right (Oxford: Oxford University Press, 2007); and Louise Doswald-Beck, "Fair Trial, Right To, International Protection," in Wolfrum, Max Planck Encyclopedia, op. cit.

Maya Indigenous Community of the Toledo District v. Belize, paragraph 184; Ebbesson, "Access to Information on Environmental Matters," op. cit., paragraph 31.

46 Savaresi, "International Human Rights Law Implications," op. cit., 72. It has also been noted that the use of this term in the Protocol was inspired by the Aarhus Convention (Koester, Nagoya Protocol on ABS, op. cit., section 5), which can in effect provide a standard for the interpretation and implementation of the Protocol in as far as Parties to that Convention are Parties to the Protocol (Chiarolla, "Role of Private International Law," op. cit., 432-233).

47 Chiarolla, "Role of Private International Law," op. cit., 445.

48 Свр Working Group on ABs, "Report of the expert meeting on compliance," UNEP/CвD/ WG-ABS/7/3. For a discussion based on the case of Japan, see Isozaki, "Enforcement of ABs Agreements in User States," op. cit., 443-444. 
the Recognition and Enforcement of Foreign Arbitral Awards. ${ }^{49}$ There is also the possibility for Parties to conclude an ex post arbitration arrangement. ${ }^{50}$

Article 18(3) does not specify which measures must be taken by Parties, but qualifies the obligation by reference to 'as appropriate,' thereby leaving flexibility to Parties in its implementation. Parties can thus choose among various ways to facilitate access to courts or alternative dispute resolution mechanisms for foreign users or providers. Insofar as indigenous and local communities are parties to MAT, consideration must be given to their customary laws and procedures, ${ }^{51}$ in accordance with relevant international human rights norms and standards. ${ }^{52}$ In that regard, it has been recommended that States ensure the best means to attain access to justice in line with indigenous peoples' selfdetermination and related rights to participate in decision-making affecting them. ${ }^{53}$ States are also expected to work with indigenous peoples to address the underlying issues that prevent them from having access to justice on an equal basis with others, and facilitate their access to legal remedies including by supporting their capacity development in making use of legal systems. ${ }^{54}$

\section{Jurisdiction and Access to Justice in Cases of Violation of Provider Country ABS Frameworks}

It is noteworthy that the Protocol does not contain a provision on jurisdiction and access to justice specifically devoted to compliance with the requirement for PIC and establishment of MAT, ${ }^{55}$ corresponding to Article 18 for the content of already established мAт. In other words, the Protocol does not

49 Chiarolla, "Role of Private International Law," op. cit., 444.

5o Ibid.

$5^{1} \quad$ Nagoya Protocol Article 12(1). See this commentary on Article 12, section 2.

$5^{2}$ See Introduction to this commentary, section 4.

53 Human Rights Council, "Expert Mechanism Advice No. 5 Access to justice in the promotion and protection of the rights of indigenous peoples," (2013), accessed 30 November 2013, <www.ohchr.org/Documents/Issues/IPeoples/EMRIP/Session6/ A-HRC-EMRIP-2013-2_en.pdf $>$, Annex, paragraph 4.

54 Ibid., paragraphs 8 and 10.

55 Note that 'With regard to illegal bioprospecting, both the applicability of the provider country's law and the user country's law can be argued. In essence, the law cannot be determined in the abstract in advance': Godt, "Enforcement of Benefit-Sharing Duties," op. cit., 431 and previous discussion at 424-431. The author concludes that 'it is possible to litigate a (meaningful) benefit-sharing claim for biopiracy in a user country's court. Prospects for success are better with regard to immaterial property than to material 
contain provisions on jurisdiction and access to justice in cases of violation of provider countries' domestic ABs frameworks under Articles 15-16. ${ }^{56}$ This may be explained by the fact that contractual arrangements can be more easily enforced in other jurisdictions thanks to the operation of private international law. Conversely legal recourse in user countries on the basis of an administrative decision embodying PIC (or lack thereof) may be difficult, as foreign courts may be hesitant to decide on the validity of foreign administrative decisions because of different administrative systems and principles of interpretation of administrative decisions. ${ }^{57}$ These cases may rather be addressed under the Protocol' compliance procedures and mechanisms. ${ }^{58}$

It has been argued, however, that the reference to 'appropriate, effective and proportionate' measures under Articles 15 and 16 may support an expansive systemic interpretation of Article 18, whereby the same jurisdictional principles and access to justice standards that apply to contractual disputes arising from MAT under Article 18(2)-(3) should be applied, mutatis mutandis, to cases of misappropriation under Articles $15-16 .{ }^{59}$ Consequently, Parties would be expected to provide opportunities to seek recourse within their jurisdiction for foreigners alleging violations by users of domestic ABS measures or for foreigners alleging inaction by a competent national authority 60 of a user country in enforcing domestic user-side measures. ${ }^{61}$ The same commentator has also argued that Parties' duty to take measures to use mechanisms regarding the recognition and enforcement of foreign judgments and arbitral awards may extend to cases of misappropriation. ${ }^{62}$

property. Against common wisdom, it is not the applicable law that forms an obstacle' (ibid., 432).

56 Chiarolla, "Role of Private International Law," op. cit., 432-434. See this commentary on Articles 15-16.

57 Tvedt, "Beyond Nagoya," op. cit., 165, 172-172 and 174.

58 See this commentary on Article 30, section 3, and on Article 15, section 2.

59 Chiarolla, "Role of Private International Law," op. cit., 435.

$60 \quad$ See this commentary on Article 13, section 3.

61 Chiarolla, "Role of Private International Law," op. cit., 434-435.

62 Nagoya Protocol Articles 15(3) and 16(3). See Chiarolla, "Role of Private International Law," op. cit., 444. 